\title{
Mothers of angels: (re)living the death of the child as a coping strategy
}

\author{
Mães de anjos: (re)vivenciando a morte do filho como estratégia de enfrentamento \\ Madres de ángeles: (re)vivenciar la muerte de un hijo como estrategia de enfrentamiento
}

Larissa Gramazio Soares ${ }^{1}$ (1)

Élida Kuchla²

Verônica de Azevedo Mazza ${ }^{1}$

Letícia Gramazio Soares ${ }^{3}$ (i)

Maria Isabel Raimondo Ferraz ${ }^{3}$ (1)

Aline Padilha Mattei ${ }^{1}$ (i)

1. Universidade Federal do Paraná, Programa

de Pós-Graduação em Enfermagem.

Curitiba, PR, Brasil.

2. Universidade Federal do Paraná, Hospital

de Clínicas. Curitiba, PR, Brasil.

3. Universidade Estadual do Centro-Oeste,

Departamento de Enfermagem.

Guarapuava, PR, Brasil.
Corresponding author:

Letícia Gramazio Soares.

E-mail: leticiagramazio13@gmail.com

Submitted on $02 / 15 / 2019$.

Accepted on 08/06/2019.

DOI: 10.1590/2177-9465-EAN-2019-0030

\section{Abstract}

Objective: To describe the experiences lived by mothers facing the death of their children. Method: A qualitative, exploratory and descriptive research conducted in Guarapuava-PR, with six participants of the "Marias" group that brings together mothers who lost their children and share their experiences to spontaneously help other women in the process of mourning. Data collection took place from May to August 2017, through a focus group. The speeches were organized by the Iramuteq ${ }^{\circledR}$ software and analyzed according to Creswell. Results: Age ranged from 28 to 40 years old, and most participants were married and catholic. The categories express the need to strengthen bonds and to create ways in which women can express themselves the importance of the social network to accommodate mourning; the relevance of ethical and humanized care; and group identity as an element to promote resilience. Conclusion and implications for practice: Describing the potentialities and weaknesses in the process of loss and grief enables a qualifying and humanizing care, overcoming care gaps, stimulating the creation of creative and dialogical spaces in maternal care. These results may guide the professional approach by considering the sociocultural context and the risk factors experienced by the mothers, by supporting the development of resilient skills and enabling a humanized and individualized care.

Keywords: Psychological Resilience; Attitude to Death; Mother-Child Relations; Mourning.

\section{Resumo}

Objetivo: Descrever as experiências vivenciadas pelas mães frente à morte do filho. Método: Pesquisa descritiva exploratória qualitativa realizada em Guarapuava-PR, junto a seis participantes do grupo "Marias" que reúne mães que perderam seus filhos e compartilham suas vivências além de ajudar outras mulheres espontaneamente no processo de luto. A coleta de dados ocorreu de maio e agosto/2017, por meio de grupo focal. As falas foram organizadas pelo software Iramuteq ${ }^{\circledR}$ e analisada segundo Creswell. Resultados: Idade variou entre 28 a 40 anos, maioria casadas e católicas. As categorias expressam a necessidade fortalecer vínculos e criar meios em que possam se expressar; importância da rede social para acolher o luto; relevância do atendimento ético e humanizado e a identidade grupal como elemento promotor da resiliência. Conclusão e implicações para a prática: Descrever as potencialidades e fragilidades no processo de perda e luto possibilita qualificar e humanizar o cuidado, com a superação de lacunas assistenciais estimulando a criação de espaços criativos e dialógicos no acolhimento materno. Estes resultados podem orientar a abordagem profissional ao considerar o contexto cultural, social e fatores de risco em que as mães vivenciam, ao apoiar o desenvolvimento de habilidades resilientes e possibilitando um cuidado humanizado e individualizado.

Palavras-chave: Resiliência Psicológica; Atitude frente à morte; Relações Mãe-Filho; Luto.

\section{Resumen}

Objetivo: Describir las experiencias vivenciadas por las madres frente a la muerte de sus hijos. Método: Investigación descriptiva exploratoria y cualitativa realizada en Guarapuava-PR, con seis participantes del grupo "Marías" que reúne a madres que perdieron a sus hijos y comparten sus vivencias además de ayudar a otras mujeres espontáneamente en el proceso de duelo. Los datos se recolectaron entre mayo y agosto de 2017, por medio de un grupo focal. Las conversaciones se organizaron por medio del software Iramuteq ${ }^{\circledR}$ y se analizaron según Creswell. Resultados: La edad varió entre 28 y 40 años, y la mayoría de las participantes estaban casadas y eran católicas. Las categorías expresan la necesidad de fortalecer vínculos y de crear medios con los que las mujeres puedan expresarse; la importancia de la red social para sobrellevar el duelo; la relevancia de una atención ética y humanizada y la identidad grupal como elemento promotor de la resiliencia. Conclusión e implicaciones para la práctica: Describir las potencialidades y debilidades en el proceso de pérdida y duelo permite calificar y humanizar el cuidado, superando las lagunas asistenciales y estimulando la creación de espacios creativos y de diálogo en el cuidado materno. Estos resultados pueden orientar el enfoque profesional al considerar el contexto sociocultural y los factores de riesgo que experimentan las madres, apoyando el desarrollo de habilidades resilientes y haciendo posible un cuidado humanizado e individualizado.

Palabras clave: Resiliencia Psicológica; Actitud Frente a la Muerte; Relaciones Madre-Hijo; Duelo. 


\section{INTRODUCTION}

Death is a subject permeated by an intense emotional burden and frequently treated as a taboo, since it is determined by diverse cultural aspects, which will imply how individuals will face the process of dying. The feelings experienced about death are also influenced by personal experiences and are directly related to the bonds established between those involved, since they carry the emotional burden in themselves, which confers authenticity and modulates the personality of each individual. ${ }^{1}$

Some cultures express death as a transition or rite of passage; in others, it refers to the human condition of fragility in controlling their ability to feel, love, suffer and, above all, die. It is therefore necessary to reflect on the complexity of this phenomenon, seeking to break the paradigm, for death will always remain a mystery, but its cross-cultural study will continue to provide unexpected insights about how humans deal with this enigma. ${ }^{2}$

Among the scenarios that cause constant reflections on the dichotomy between life and death is gestation, which above all represents the beginning of life. ${ }^{2}$ For many women, motherhood symbolizes the expression of the feminine, as an assertion of her role in society and in the continuity of life, the maternal role inherent to the female population, thus emerging as an important gender issue to be discussed. ${ }^{2,3}$ The affective experience of attachment between the mother-child binomial is immeasurable, however, when broken, it causes pain and suffering in all dimensions, from the physical, social, psychic, and emotional ones to the spiritual one..$^{2,3}$

For a mother, losing a child generates the loss of the way of existing. She cannot find one social "status", since she remains a mother but of a dead son, ${ }^{4}$ which makes it difficult to find overcoming strategies. In a study conducted with a group of nine mothers who lost children under one year of age, belief and faith support, family support and support from health services were associated to the possibility of coping with death. ${ }^{5}$

Facing adversity, such as the loss of a child, allows one to think that a person has the potential to develop and achieve acceptable levels of health and well-being. These skills allow tolerating, managing and alleviating the psychological, physiological and social consequences of traumatic experiences. Not all individuals exposed to adversity undergo continuous illness or suffering but, on the contrary, there are those who have their mental or physical health maintained or recovered despite significant stress or adversity. Conceptually, they are called resilient people because it refers to the phenomenon in which many individuals adapt to life's challenges and maintain mental health despite exposure to adversity, ${ }^{6}$ this being the central object of investigation of this study.

It is important to understand these maternal processes in order to develop interventions to reduce the effects of shortand long-term psychological distress in this population. In this context, health professionals, especially nurses, should be prepared to develop strategies that strengthen resources for this coping effort and to develop interventions based on mothers' sources of support to increase their ability to adapt to the loss of a child. ${ }^{7}$

Despite the growing interest in studying the process of loss and grief, this theme has been little explored from the maternal point of view after the loss of a child and the availability of scientific production can still be characterized as scarce. ${ }^{8}$

Considering the importance of this theme in the existing scope, this study is justified as a possibility to contribute to a better understanding of the loss and grief process from the maternal point of view and, from this perspective, to promote reflections on possible care strategies in the various work contexts of nurses and of other health professionals.

Thus, and considering the need to establish an attentive look at mothers who suffer from the loss of a child and its potential for theoretical and practical applicability, the following question was asked: "How does the mother the death of her child?" This study aims to understand the experiences lived by mothers facing the death of their child.

\section{METHOD}

This is a descriptive exploratory study of a qualitative character. Considering the research as qualitative allows to understand the participant in a certain social condition, belonging to a particular social group or class, with their beliefs, values and meanings, and descriptive because it aims to describe the characteristics of a given population or phenomenon, allowing the researcher to study life conditions, gather opinions and attitudes of a population by means of analysis, recording and interpretation of phenomena, seeking to describe and to interpret them. ${ }^{9}$

This study was conducted with women who were members of a group called "Marias" in the city of Guarapuava-PR, located $250 \mathrm{~km}$ from the state capital. This group emerged in 2016, from the initiative of a member to locate and reunite other women who have experienced the same situation and to share their experiences; it now has the effective participation of six women who had lost their children and spontaneously help other women in the grieving process. It aims to motivate, inspire, encourage and make room for love, joy and life to flow after the difficult and painful moment of losing a child. The group's work is publicized by local media, in a journal, in television and in social networks, and the group's name is a reference to Mary, mother of Jesus.

Due to the dissemination and visibility of the group, they were invited to participate in the research through an invitation sent by social media, informing about the researcher's education, interest in the subject and the research objectives. The participants did not know the researcher previously. Sampling was intentional; the inclusion criteria were to being participant of the "Marias" group, being over 18 years old and accepting to participate in the research; therefore, all the members of the group agreed to 
participate in the study and signed the Free Informed Consent Form (FICF). The age of the dead child was not a criterion for this research, just as it is not a criterion for the mothers' participation in the group. Thus, mothers who experienced the loss of children under two years old participated in the research, including gestational losses.

Data collection was performed through a Focal Group (FG), since it is a qualitative research strategy which provides the investigation of complex issues that generate knowledge from the interaction among individuals and discussions of group thinking, providing richer reflection and answers and original ideas. ${ }^{10}$

Two focus group sessions were held. In the second session, no new elements were reported, and the speeches obtained previously were sufficient to understand the phenomenon. Thus, saturation of data was reached. In the invitation sent to participate in the research, the choice of place was left free by the participants who chose it to be held at the residence of one of the researchers, due to the group's preference, besides setting up a neutral and welcoming environment, in order to allow greater freedom to talk about the topic. The relationship between researcher and participant was limited to the invitation to participate in the research and to the execution of the focus group. The first session lasted two hours and thirty minutes and three mothers participated, while the second session took place for three hours and four mothers were also present, with one of these mothers participating in both groups.

To guide the $F G$, a thematic guide with seven questions was used, among them: "Tell me how it is for you to have experienced the loss of a child"; "How did you face and/or do you face this situation?"; "How does the group help cope with the loss of a child?"; "How did you help yourself to cope with the loss of a child?" In order to comply with the methodological rigor of the study, the FG was audio-recorded and conducted by three researchers with ample experience in qualitative data collection, one undergraduate student and one doctoral student who were responsible for conducting and directing and a third researcher, also a PhD student, who made notes related to the participants' expressions and behaviors, aiming at the non-biased polarization of the results obtained. Afterwards, the focus group sessions were transcribed and returned to participants by e-mail, already identified with pseudonyms to ensure the confidentiality and anonymity of the participants to make the correction and review.

Data was organized by two of the researchers, one of whom was not present during the focus group sessions, thus preserving the strangeness of the data. The IRAMUTEQ ${ }^{\circledR}$ (Interface de R Pour Analyses Multidimens lonnelles de Textes et de Questionnaires) software was used; it is free and acts on open source logic, licensed by GNU GPL (v2), and binds to the $\mathrm{R}$ software and the phyton language, which has a statistical function. ${ }^{11,12}$ For this, it was necessary to transcribe the speeches expressed by the mothers during the $\mathrm{FG}$, so that the texts were crossed. So the transcripts were inserted and organized in the IRAMUTEQ software, and later grouped after their coding.
Through frequency and similarity, it was sought to understand the central objective of this research from the six classes that were identified during the analysis process, which presented 554 text segments, 20,102 occurrences, 2,504 numbers of shapes, hapax with $51.60 \%$ and $78.9 \%$ utilization. The resulting classes of data organization by the software represented through a dendrogram reveal the environment of meaning of the words and can indicate the subject's speech, and the researcher's gaze is a reference to the understanding and amplitude of the studied object. ${ }^{11}$

After data organization by means of the software, data was subjected to thematic analysis independently by two of the researchers following the steps proposed by Creswell. ${ }^{9}$ This is a set of qualitative analysis techniques based on the extraction of the meaning of the data from the text resulting from the interviews, in which the researcher must reflect on these and deepen in search of their meaning, guided by the following steps, namely: data organization and preparation, data reading, coding, description, discussion and interpretation. ${ }^{9}$

This study was conducted and reported according to the Consolidated Criteria for Reporting Qualitative Research (Critérios Consolidados para Relataruma Pesquisa Qualitativa, COREQ) guidelines to validate this report. ${ }^{13}$ All ethical precepts have been respected and received approval from the UNICENTRO Ethics Committee according to opinion No. 2.073.311. In order to preserve the identity of the research participants, the characteristics learned in the focus group sessions and that were remarkable were sought, finding their appointment assigning stars pseudonyms for believing that they are celestial bodies that serve as guidance for many navigators, as well as having their own sparkling radiant glow that brings beauty to the sky even on dark nights. ${ }^{14}$ It was sought to treat the subject with the due sensitivity required for the study, according to the approach of the proposed theme; in addition, this decision was shared and enthusiastically accepted by the participants.

\section{RESULTS}

The first topic describes the data on the general characterization of mothers and later their history, in order to contextualize the subjective reality of the participants so as to guide the analysis of the reports. Subsequently, the data related to the approach of the central theme of the study.

As for the social data of the six study participants, all lived in the city of Guarapuava-PR, and their age ranged from 28 to 40 years old. Four declared themselves white and two brown. Regarding marital status, five had a partner and one was divorced. When questioned about religion, all reported being Catholic. As for schooling, one had completed high school, but was attending undergraduate Nursing and the others had completed higher education and, among the professions, there was a physical educator, a psychologist, a social worker and a pedagogue, all active. One participant reported having a degree in Law, but now acted as a doula. Regarding the number of children, four 
participants reported having another child in addition to the one who died, ranging from four to nine years old, and only one had no live children yet.

\section{Knowing the story of mothers and their children}

Phoenix represents the bird that is reborn from the ashes and later becomes a constellation; this name was given to this participant because it was her initiative to create the "Marias" group. She lost her daughter in 2011, one year and two months old. A while later, she reports she dreamed of Our Lady Aparecida, where she received a call to unite "mothers of angels".

The second participant is the Mayan star, because she is idealistic and inspired; the name with a Greek origin means "the mother". In 2016, pregnant with prematurely born girl twins, hospitalized at birth, one of whom died in the first week of life. For five months, she stayed with the other daughter who remained hospitalized and did not experience her mourning. After discharge, Mayan felt the suffering caused by the death of one of the twins more intensely, expressing that it was in the group that she found the strength to face the loss of her daughter.

Merope has the name given by the meaning of "honey mask", with her charitable and unveiled personality; she experienced the loss of four children. Her first mourning was 11 years ago and the most recent in 2016, being two gestational losses and two babies who were born prematurely and then died. A carrier of thrombophilia, she reveals that the group was a support point for coping with the loss of her children.

The Zaniah star gives off freshness, charisma and personality. Her history of loss occurred five years ago when, after a planned and uneventful pregnancy, she gave birth to her 36-week-old son who had difficulty breathing at birth and eventually died due to complications. She expresses that with the group she can reveal and share their feelings.

Veja has a name witha Iberian origin and its meaning related to fertility. Seven years ago, after a seemingly normal night's sleep, she got out of bed to see her three-month-old son, when she picked him up to her lap, she realized that he was not breathing, called for help and after pre-hospital care, his sudden death was attested. She states that in the group she found a way of strengthening to face the loss.

Finally, Pollux had its name given due to her kindness. She idealized and planned to be a mother but she had a miscarriage at nine weeks of gestation. She believes that society sees her gestational loss as irrelevant and easily recoverable compared to others, but says she suffered a lot and found warm support in the group for her pain.

Through word frequency analysis with the IRAMUTEQ ${ }^{\circledR}$ software, the dendrogram was formed, resulting in six classes, which were distributed in such a way due to the basic lexicography of the words, as shown in Figure 1, which indicates the percentage of text segment by class.
Due to the similarity between some classes, it was decided to bring them together so that the purpose of the study could be described with greater qualification. Classes 1 and 2 were grouped into categories and referred to as "(Re)Living the loss in the pursuit of resignification"; Class 3 was entitled: "Welcoming as a possibility for resilience" and, due to its similarity to Classes 4 and 5, it gives rise to the category of "Health care as an obstacle to coping"; and finally, Class 6 , "The group photographic experience as a promotion of resilience". Presented and discussed below:

\section{(Re)Living the loss in search of resignification}

This category presents attachment to other children as a positive way of looking at the child's death. Some participants reveal a way of lovingly (re)living, in the mother's imagination, what it would be like if their child were present, without grief and suffering, but with joy to observe other children in the same phase of life, thus showing signs of a lighter and more resilient vision. This can be observed in the following speeches:

And when my daughter passed away, my cousin was pregnant, so I clung to her baby, I follow her growth to this day, always wondering. And she sends me a message when her daughter learns something new, lost her first tooth, learned to write: Look, your daughter was going to be in this stage. And that's cool, to get attached. (Phoenix Star)

When I see the other's son I think, would my son put the pan on his head too? (Zaniah Star)

Although for some mothers daily comparison is a positive method, for another mother this corroborates to frequent sadness and, consequently, can become a hindrance in coping with loss and grief, as expressed by the Mayan star:

I finish feeding my daughter I think I should be doing it all over again (to the other daughter who passed away). Sometimes I'm quiet, I'm relaxing and I think I should be giving another bath, I should have work doubled. (Mayan Star)

Recalling the moment of death, being able to speak openly about feelings and memories, and sharing the sadness and longings with people who have experienced similar processes proved to be an effective and curative method for these mothers, as observed in the following speeches:

Gestational loss is the one that for people, is to be the fastest and most irrelevant. They say soon comes the next, this happens to everyone, I had several examples. 
Figure 1. Dendrogram of the Descending Hierarchical Classification (DHC).

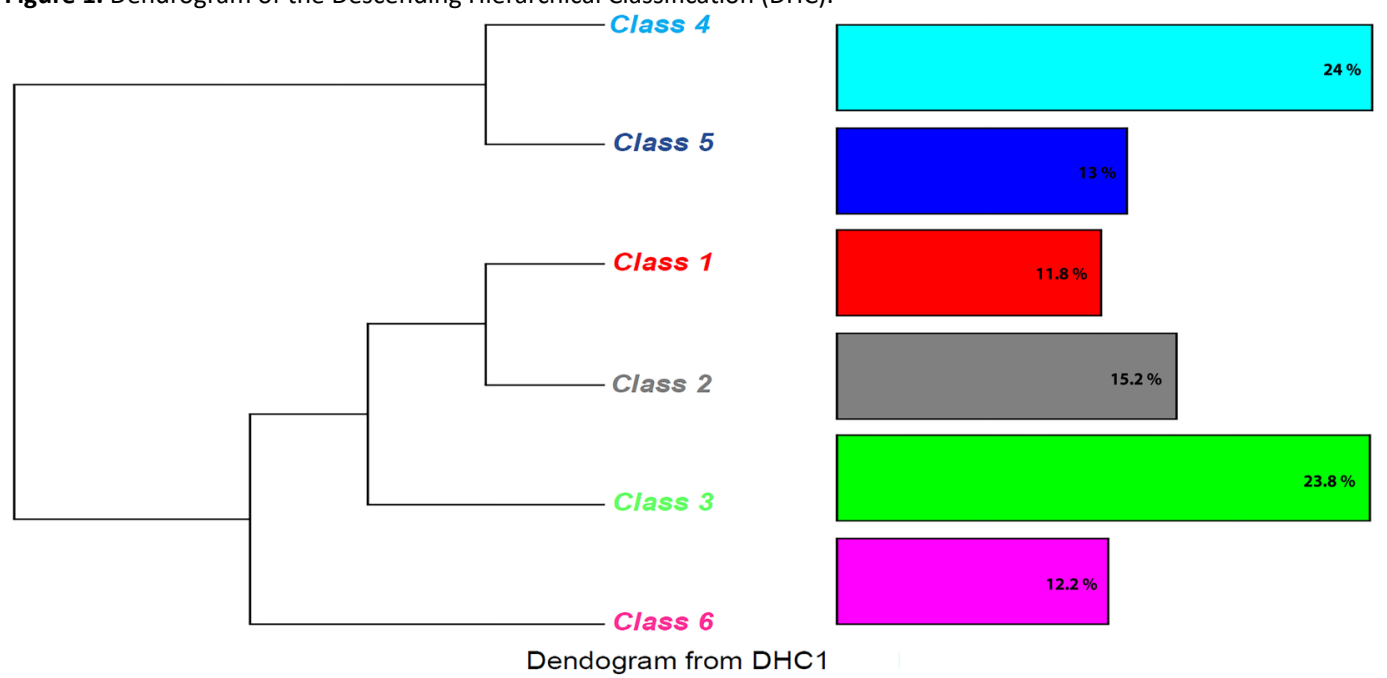

And my daughter's name, I could only say her name after the group, she was very planned, very desired (crying...). (Pollux Star)

I was able to tell, tell what I was feeling one to the other, I will tell, and she will be understanding me. (Veja Star)

Being able to imagine the child growing and developing brings about ambiguous sensations, permeated by singular experiences that should be stimulated if timely and worked on in search of the (re)signification of this opportunity. Sharing feelings with people who create an identity, and keeping the child's memory alive, has contributed to lessen suffering and to favor the development of resilience resources.

\section{Welcoming as a possibility for resilience}

This category exemplifies how family members and members of society can facilitate or hinder the coping process after the child's death. Death is uniquely faced by each individual; not everyone can speak with the same spontaneity, especially when it is about a loved one. Overseeing the issue, mainly by family members, was a form of protection. Even understanding this, the mothers of this study report that the attempt to omit the death of their child imposed barriers in coping with loss and grief, as shown in the following speeches:

The family goes over it, nobody wants to talk to you about your loss, because they want you to forget, to be happy. My mother herself, she prefers to pretend she didn't even exist, she doesn't like me talking, that's the worst for me, I think. (Phoenix Star)

My grandmother is also a Maria (as they call themselves in the group), and I heard my grandmother talking about her daughter who died all her life, and I remember that nobody welcomed, nobody paid attention, people didn't even consider what she was talking about. (Mayan Star)

The support and sensitivity of a welcoming network, composed of family and friends, seeking to understand the mother's weaknesses was essential to maintain her mental and physical health after the loss, as we can see:

She helped me a lot, my comadre was a person who listened to me, and who talks about my daughter to this day. (Pollux Star)

Thank God I have support, my mother is a spiritist, and she says, I have so many grandchildren, she encompasses the children I lost. And my father too... already, next to my husband, that's not the case. (Merope Star)

My daughter is five years old, and since she was very young, she always knew what happened. Last month she found some pictures of the brothers and they were there at my mother's house and said these are my brothers (...) now to anyone who gets home she says: I need to show the photo of my brothers. (Merope Star)

In addition, feeling that other people depend on your liveliness is also a way to help you cope with the death of a child.

This is what I think, that the one who saved me from sinking was my oldest daughter (...) I couldn't face her beaten, sad, because she was too, and I had to take care of her before treating myself, so, I always tried to give the best explanations, have the best reactions, lying, but, I had to, and that's what saved me, I had to lift her. (Mayan Star) 
The reports reveal a major impasse, which is the omission of the dead son before family and society. Talking about what happened, remembering moments, looking at photos and memories, and sharing them with others is one of the most effective resources in the resilience process. For them, anguish and longing alone cause pain and suffering; however, they can be alleviated if shared. By hiding allied feelings of unwillingness rather than protecting from pain, increasing mutual support and strengthening support networks can be the key to making grief milder, with a path towards resilience.

\section{Health care as an obstacle to coping}

This topic presents how immediate health care negatively influenced mothers' coping. Bad and traumatic experiences with health professionals have been reported, either because women believe them to have occurred, such as unethical attitudes, lack of resources and information, with an explicit dehumanization in care, as reported below:

The pediatrician came into the room and said: your son is in the ICU because he has difficulty breathing, and I asked him: is he ok? He replied that if he was fine, he wouldn't be there and left. I did not know what it was not to be well, if he run any risk (...) then they let me in and it was not even five minutes they took me out of there, did not let me look or take anything. (Zaniah Star)

The doctor started taking all his clothes off, and my mother asked why, and she said it was to see if he had any bruises, if he hadn't been beaten. And, she just took his clothes off, turned everything around, looked at him and left him on the couch just like that, and handed me a paper! I felt like vomiting, but she didn't understand. (Veja Star)

The negative experiences lived with health professionals resulted in the lack of later confidence, difficult to be reversed, representing an obstacle in the trajectory of resilience, as observed in Zaniah's speech:

Today I have a feeling that I will never believe anyone in health when they tell me everything is fine, until I see that everything is fine, because I can't believe it anymore. (Zaniah Star)

On the other hand, humanized care and ethical and responsible care, based on respect and sensitivity, represent an important element that promotes well-being and healthy coping with grief. We relate the speeches of Pollux and Veja to this:

A nurse held my hand and said you'll come back here, and I'll see your next child and I'll hold him in my arms, the next child you have... I think she even exaggerated, but that gave me so much strength, and after she said that, I became someone else, even relaxed. (Pollux Star)

The psychologist was tough, but if it wasn't for her, l'd never picked him up after he passed away. She said: take him on your lap! And I said I didn't want to take it, and she said take it, because you will never take it on your lap, then handed it to me. That was the time I felt him, that I saw that he had passed away that I realized it was over! I packed the clothes, cuddled him, came to the funeral home, I put him in the little coffin. (Veja Star)

Looking for answers and explanations about health situation or mortis cause of the beloved one is something natural in the process of mourning, as expressed by the mothers. However, the difficulty in obtaining information about the child from health professionals about what happened that caused his death, corroborated these questions. The unpreparedness and lack of humanization of these professionals had negative implications on the lives of these mothers and represent a hindrance to coping.

\section{Photographic experience and the group as resilience promoters}

This category expresses the meaning that the "Marias" group and the photographic experience represent for the mothers participating in this research in their trajectories. It is noteworthy that this trail took place in 2016 , so it is not a methodological part of the research, but it was an important fact mentioned by the group. It is a photographic trail of the group so that they could re-live the mourning and turn it into a positive message for other mothers, expressing the feeling they could not express. For them, photography was felt in the real sense of that word, as a form of catharsis, that is, the way these mothers used to soften the trauma experienced. Accordingly, we can observe the expression of the following participants:

The idea of taking some pictures exposing the mourning was very strong, because sadness came, and we fell into a very deep cry, we felt that pain of mourning, we relived the veiling, the return home without the son, from the cemetery, from the burial, to leave your son's body there. It was very intense! Then we started singing a song, we made a circle naturally, we started dancing, there was another mood that invaded. Very surprising. (Mayan Star)

We relived the grief, re-lived the loss... And then if you look at those pictures you see mourning and light differently, you see that you can experience mourning lightly. Not that you will forget, just live another way! To live better! Anyway, you must live, so live well. (Phoenix Star) 
It was a bond with the children, because we started singing out of nothing, very childish, very interesting, and it was such a peace in everyone's heart. (Merope Star)

For them, the greatest source of support in the trajectory for resilience was given by people who experienced similar situations, when creating identity and developing feelings of belonging by experiencing the same circumstances, because they can understand the whole process lived by identifying with each other, as reported below:

If it were to summarize our group and with the sensation of not being alone anymore, it was an eternal loneliness. (Zariah Star)

When I hear a new story, when a new mother arrives, I live that there and it's automatic, you compare! It's inevitable! You hear another story and you re-live that because you can understand that pain. (Mayan Star)

I don't need to be careful of what I'm going to say, I don't have to worry about what they will think, even if I'm expressing or telling a very bad feeling. If I tell you, you will be amazed, you will not understand. (Mayan Star)

After the group, the sense of helplessness and unpreparedness to face the loss of their child was replaced by the path of resilience. The longing still comes to light, however, according to the mothers' report, now seen in a lighter way with less suffering. The group and the photographic experience led to the acceptance that they really are "mothers of angles" as they call themselves, and the previously unremitting sadness paved the way for something new, altruism and benevolence, to support each other.

\section{DISCUSSION}

When analyzing the experiences lived by mothers facing the death of their children, we identified elements that contributed and others that hindered the process of coping with loss and grief.

During the interviews, it was possible to see how devastating the death of a child is for a mother; the feelings expressed by them immediately after the loss and before participating in the Marias group were the following: sadness, suffering, depression and non-acceptance, seeking answers, and feeling guilty for what happened. The literature also states that parents facing their children's death are out of touch with the horrible pain they feel and which cannot be compared to anything previously experienced. ${ }^{8}$

The feeling expressed by one of the participants who had a fetal loss is reiterated; the authors of a recent research assert the attention that the health professional should have on the mother with fetal death and stillbirth. This type of loss causes the woman to shake her self-esteem with feelings of inferiority for not being able to give birth to her live child and blaming herself for the dead child. In addition, mourning for fetal or stillbirth is considered as an invisible mourning which, in society's eyes, is not a cause of suffering in the mother. ${ }^{3}$

In this sense, to alleviate this suffering mothers saw the expression of the moments lived with their child, the moment of death and the appreciation of the child before the family as a way out, therefore breaking with the social paradigm and expressing themselves about the loss of a child, thus re-living moments of the loved one, it helps in coping. In an attempt to protect the mother and themselves from suffering, family members and friends veil the matter. ${ }^{8,15}$ However, this was one of the obstacles identified by the study participants to cope with loss and grief, being important to open spaces and moments to talk about death and feelings about what was experienced.

In a phenomenological research on maternal mourning, it was possible to relate the same desire, that of perpetuating the memory of the child. ${ }^{4}$ In this sense, corroborating these findings, when the family becomes absent and avoids recalling the issue, the mother may feel helpless and unprepared to pursue resilience. Preserving the memory of children represents a form of tribute, aids in alleviating pain and ensures that they will never be forgotten. ${ }^{16}$ This represents one of the pillars of resilience of the initiative, which refers to the desire for the perpetuation of memory, as reported by the study participants, in which the mother seeks memories of her child, rescuing memories instead of suffering, thus emerging a resignification of grief and resilience. ${ }^{17}$

It is also verified that the loss process implied the approximation to other family members, in the search for sharing the pain experienced. This result is in line with other research that sought to understand how mourning alters the daily lives of parents who had deceased children, and which asserts in its results that having the support of family and friends is crucial for the differential adaptation in the face of adversity, where the shelter received results in the bereaved person that their own efforts and eigenvalues are being nourished and strengthened, finding the strength to overcome mourning. ${ }^{18}$

This result is related to another pillar of resilience: the ability to relate. It presupposes that closer emotional and intimate ties with other individuals is a key to the mother's positive performance in the search for resilience, ${ }^{17}$ the need for reconstruction is also necessary; it can be asserted that the mother's involvement with the support network is encouraging and promotes open dialog with a revelation of the feelings experienced.

In addition to the mother's social support network being important in grieving and in achieving resilience, the care of health professionals is an essential part in this process, as expressed by the mothers of this research. The moment of receiving the news of the death of the child is the most difficult and distressing one, so the support of the health professionals becomes crucial for a better development of grief. Professionals must be sensitive and empathetic in order to promote respect when expressing the 
feelings exposed by the mother. Doing so may help the bereaved mother to more easily cope with the pain of loss. ${ }^{16}$

Communicating bad news is undoubtedly one of the most difficult tasks in health care, since it is recognized that the way it is conducted can seriously affect the person involved and have negative impacts on coping. The best practices adopted by professionals who need to communicate bad news require open and empathic reporting so as not to be emotionally decompressed with the public; rather, it is based on understanding the emotions. Professionals not only need to establish facts that happened quickly, but also need to go beyond informing the causes, critically; they must manage the emotional problems that emerge in this event and that is part of their professional performance. ${ }^{19}$

Based on the reports presented, it is also reiterated that the health professional should provide actions that later facilitate the grieving process, such as: contact with the child who is in a serious condition in an ICU, letting the mother hold the child on her lap, thus providing a sensitive care, and providing true information, as it is known that such strategies decrease the feeling of emptiness in the event of a child's death. ${ }^{1}$

It is extremely important to strengthen the grief care network, expanding the understanding and the ways of receiving the pain and experiences of bereaved mothers, through support groups within health facilities, in order to provide mutual support of women who went through the same situation. ${ }^{4}$ The use of groups by trained professionals is a facilitating strategy in coping with grief and resilience, taking into account the sense of belonging that surrounds the person. ${ }^{20}$ To this end, the group in which the mothers in this study are part of found a different strategy for working with grief and resilience, the photographic experience, as they call it, being one of the sources that provided the most positive coping of suffering for the death of the child. This form of coping is considered as the pillar of creativity within the trajectory of resilience, since it can be considered as a process of innovation, order and beauty creation amidst disorder and chaos, in which cognitive, affective, emotional, and social skills were used for its creation. ${ }^{17}$

The literature regarding the use of photography as a resilience promoter for mothers who experienced the death of their children is scarce. However, studies have been found that refer to photography as a growth-enhancing method that is advantageous and effective in psychological research. ${ }^{21}$ The images captured in photos cannot be silenced with words and when, shared with others who have similar experiences, they have the power to resurrect hitherto silenced subjectivities. ${ }^{22}$

This feeling expressed by mothers after the photographic experience portrays the acceptance of the loss, which is characterized when the individual accepts inwardly that the object of desire has been lost and that there is no turning back, which guarantees the "ego" inner acceptance and, with it, it can be said there is the "cure" for mourning. If not the proper cure, there will be a harmonious coexistence between the lost object and the desire to possess it. ${ }^{7}$ According to the research participants, for the mothers of this research, this photographic experience provided the cure of suffering and a more altruistic and benevolent view of the loss.

The mother who loses a child will never forget him, there will always be room for him in her thoughts, but it is possible to live well after the loss and to rediscover the meaning of life. There is no rule for this but ways to facilitate the search for the reunion of the meaning of life, as the mother's feelings allow. ${ }^{8}$

\section{CONCLUSIONS AND IMPLICATIONS FOR PRACTICE}

This study allowed knowing the experiences lived by mothers facing the death of their children, even in the early years of life, which indicates the need to strengthen bonds and to create ways in which mothers can express the feelings that arise after such a painful loss. In addition to reasserting the relevance of the presence of the support network with which they can talk to, without suffering the existing taboos about death. It also exposes the importance of ethical and humanized care by health professionals, with a qualified reception, combined with the appropriate treatment of the physical, psychological and emotional effects caused by the death of the child. In addition, group identity emerged as a fundamental promoter element in the trajectory of resilience, with its apex during the photographic experience.

The contribution of experiences lived by the mothers of this study for nursing care is pertinent because it can guide approaches guided by resilience, considering the importance of instrumentalizing the sociocultural context, the risk factors in which mothers are inserted, with a view to supporting the development of resilient skills, and enabling a humanized and individualized care, including their real needs given the harsh reality that occurred. Moreover, it is hoped that it can stimulate creativity in professionals in the elaboration of actions aimed at holistic care for this population, often ignored in health services.

Some limitations are assumed for being developed in a specific scenario where the results obtained do not allow generalizations and, in this way, caution is suggested in applying and comparing these results. In addition, there is a lack of national and international scientific productions, especially by nurses on this subject. Despite the limitations of the study, it opens the perspective for the need for further studies of this nature, because there is still lack of evidence of efficient actions with regards to the mother who suffers from the death of her child. The findings of this study are expected to contribute and encourage further research to understand and recognize the process of loss and grief with participants other than mothers, such as paternal and other family members' suffering, and to include other conditions that imply resilience to the child's chronic condition and/or malformation, and may include the perception of professionals in recognizing their role in this process. 


\section{REFERENCES}

1. Nery MP. Vínculo e afetividade: caminho das relações humanas. $3^{\underline{a}}$ ed. São Paulo: Ágora; 2014.

2. Abramovitch H. Death, Anthropology of. International Encyclopedia of the Social \& Behavioral Sciences. 2015 set; [cited 2019 jul 27]; 5:870873. Disponível em: https://www.sciencedirect.com/science/article/ pii/B9780080970868120525 DOI: https://doi.org/10.1016/B978-0-08097086-8.12052-5

3. Murphy S, Cacciatore J. The psychological, social, and economic impact of still birth on families. Seminars in Fetal and Neonatal Medicine [Internet]. 2017 jun; [cited 2019 jul 27]; 22(3):129-134. Available from: https://doi.org/10.1016/j.siny.2017.02.002

4. Freitas JL, Michel LHF. A maior dor do mundo: o luto materno em uma perspectiva fenomenológica. Psicol Estud [Internet]. 2014 abr/jun; [cited 2018 mar 02]; 19(2):273-283. Available from: http://www.scielo.br/pdf/ pe/v19n2/10.pdf DOI: http://dx.doi.org/10.1590/1413-737222324010

5. Lopes BC, Borges PKO, Grden CRB, Coradassi CE, Sales CM, Damasceno NFP. Luto materno: dor e enfrentamento da perda de um bebê. Rev Rene [Internet]. 2017 mai/jun; [cited 2018 aug 19]; 18(3):307-13. Available from: https://www.redalyc.org/articulo.oa?id=324053754004 DOI: http://doi.org/10.15253/2175-6783.2017000300004

6. Chmitorz A, Kunzler A, Helmreich I, Tüscher O, Kalisch R, Kubiak T, et al. Intervention studies to foster resilience - A systematic review and proposal for a resilience framework in future intervention studies. Clin Psychol Rev [Internet]. 2018 feb; [cited 2018 oct 16]; 59:78-100. Available from: https://www.sciencedirect.com/science/article/pii/ S027273581730020X?via\%3Dihub DOI: http://doi.org/10.1016/j. cpr.2017.11.002

7. Rossman B, Greene MM, Kratovil AL, Meier PP. Resilience in Mothers of Very-Low-Birth-Weight Infants Hospitalized in the NICU. J Obst Gyn Neo [Internet]. 2017 mai/jun; [cited 2018 oct 14]; 46(3):434-445. Available from: https://www.jognn.org/article/S0884-2175(17)30004-7/pdf DOI: http://doi.org/10.1016/j.jogn.2016.11.016

8. Borges MS, Mendes N. Experiences on facing death: social representations of relatives of patients that have no possibility of a cure. REME Rev Min Enferm [Internet]. 2012 abr/jun; [cited 2018 aug 21]; 16(2):217-224. Disponível em: http://www.reme.org.br/artigo/detalhes/522

9. Creswell JW. Projeto de Pesquisa: método qualitativo, quantitativo e misto. $3^{\mathrm{a}}$ ed. Porto Alegre: Artmed; 2010.

10. Gatti BA. Grupo focal na pesquisa em Ciências Sociais e Humanas. Brasília: Líber Livro Editora; 2005

11. Camargo BV, Justo AM. IRAMUTEQ: um software gratuito para análise de dados textuais. Temas Psicol [Internet]. 2013 dec; [cited 2019 jan 30];21(2):513-518. Available from: http://pepsic.bvsalud.org/scielo. php?script=sci_arttext\&pid=S1413-389X2013000200016\&lng=pt DOI: http://dx.doi.org/10.9788/TP2013.2-16

12. Iramuteq. Interface de $\mathrm{R}$ pour les Analyses Multidimensionnelles de Textes et de Questionnaires. Um logiciel libre construit avec des logiciels libres. Tolouse: Pierre Ratinaud; 2016; [access 2016 feb 20]. Available from: http://www.iramuteq.org/
13. Tong A, Sainsbury $P$, Craig J. Consolidated criteria for reporting qualitative research (COREQ): a 32-item checklist for interviews and focus groups. Int J Qual Health C [Internet]. 2007 dec; [cited 2017 aug 30]; 19(6):349-57. Available from: https://doi.org/10.1093/intqhc/ mzm042

14. Almeida CSL, Sales CA, Marcon SS. O existir da enfermagem cuidando na terminalidade da vida: um estudo fenomenológico. Rev Esc Enferm USP [Internet]. 2014 feb; [cited 2017 aug 30]; 48(1):34-40. Available from: http://www.scielo.br/scielo.php?script=sci arttext\&pid=S008062342014000100034\&Ing=en DOI: http://doi.org/10.1590/S0080 623420140000100004

15. Morelli AB, Scorsolini-Comin F, Santos MA. Impacto da morte do filho sobre a conjugalidade dos pais. Ciênc Saúde Coletiva [Internet]. 2013 sep; [cited 2017 sep 30]; 18(9):2711-2720. Available from: http://dx.doi. org/10.1590/S1413-81232013000900026

16. Nogueira EL, Nascimento ARA. Maternidade e Identidade em Mulheres que Perderam Filhos: Aspectos Psicossociais. Interação Psicologia. 2014 jan/abr; [cited 2019 jul 27];18(1):25-36. Available from: http:// dx.doi.org/10.5380/psi.v18i1.28387

17. Mellilo A, Estamatti $M$, Cuestas A. Alguns fundamentos psicológicos do conceito de resiliência. In: Melillo A, Suárez O, Ojeda EN. Resiliência: descobrindo as próprias fortalezas. Porto Alegre: Artmed;2005. p.60-72.

18. Santos $\mathrm{SH}$, Oliveira W, Jesus CF. Pais enlutados na sociedade atual: uma análise sobre suas vivências cotidianas a partir de novos critérios diagnósticos. Rev Ciên Hum UNITAU [Internet]. 2015 jun; [cited 2019 jul 27];8(1):98-108. Available from: https://www.rchunitau.com.br/index. $\mathrm{php} / \mathrm{rch} / \mathrm{article} / \mathrm{view} / 251 / 0$

19. Tan KKY, Pang A, Kang JX. Breaking bad news with CONSOLE: Toward a framework integrating medical protocols with crisis communication Public Relations Review [Internet]. 2019 mar; [cited 2019 ju 27];45(1):153-166. Available from: https://www.sciencedirect.com/ science/article/pii/S0363811117303697 DOI: http://doi.org/10.1016/j. pubrev.2018.10.013

20. Giffoni Filho JAR. A resiliência e seus desdobramentos: a resiliência familiar. Rev Psicol Pt. 2014; [cited 2019 jul 27]. Available from: http:// www.psicologia.pt/artigos/textos/A0806.pdf

21. Adegoke CO, Steyn MG. A photo voice perspective on factors contributing to the resilience of HIV positive Yoruba adolescent girls in Nigeria. J Adolesc [Internet]. 2017 apr; [cited 2018 aug 30]; 56(1):10-10. Disponível em: https://www.sciencedirect.com/science/ article/pii/S0140197117300039 DOI: https://doi.org/10.1016/j. adolescence.2017.01.003

22. Touso MFS, Mainegra AB, Martins CHG, Figueiredo GLA. Photovoice como modo de escuta: subsídios para a promoção da equidade. Ciênc Saúde Coletiva [Internet]. 2017 dec; [cited 2018 mar 01];22(12):38833892. Available from: http://www.scielo.br/scielo.php?script=sci arttext\&pid=S1413-81232017021203883\&Ing=pt DOI: http://dx.doi. org/10.1590/1413-812320172212.25022017 